\title{
KONSEP PENINGKATAN KUANTITAS DAN KUALITAS PROGRAM LEGISLASI NASIONAL: REKOMENDASI KONSEPTUAL DAN KEBIJAKAN PADA PROLEGNAS 2015-2019
}

(The Concept of Improving the Quantity and Quality of the National Legislative Program: A Conceptual and Policy Recommendation for National Legilative Program 2015-2019)

\author{
Muh. Risnain \\ Fakultas Hukum Universitas Mataram \\ Jl. Majapahit No.62 Mataram-NTB. \\ Email: risnain82@gmail.com dan ris_bdg@yahoo.com
}

Naskah diterima: 15 Oktober 2015; revisi: 27 November 2015; disetujui:2 Desember 2015

\begin{abstract}
Abstrak
Rendahnya capaian Prolegnas baik dari sisi kuantitas maupun kualitas pada dua periode Program Legislasi Nasional (Prolegnas): periode 2005-2009 dan periode 2010-2014, merupakan persoalan krusial pembangunan hukum yang harus dipecahkan. Dampaknya bukan saja minimnya capaian Prolegnas, tetapi pada eksistensi negara hukum Indonesia. Penelitian mengidentitifikasi dua permasalahan, Pertama, apa saja hal-hal yang menghambat tercapainya target Prolegnas pada periode 2005-2009 dan periode 2010-2014? Kedua, bagaimanakah konsep peningkatan kualitas dan kuantitas Prolegnas pada masa yang akan datang? Jenis penelitian adalah penelitian yuridis normatif. Penelitian ini menyimpulkan bahwa untuk meningkatkan kualitas Prolegnas, maka ketika pembahasan Rancangan Undang-Undang (RUU) oleh DPR, Pemerintah dan DPD hendaknya memperhatikan hal-hal: harmonisasi vertikal materi RUU dengan UUD NRI 1945 dan harmonisasi horizontal RUU dengan peraturan perundang-undangan, tingkat urgensitas dan kompatibilitas materi muatan undang-undang, dan peningkatan kapasitas legislative drafting anggota legislatif. Untuk menjamin peningkatan kuantitas Prolegnas, maka hendaknya ketika penyusunan RUU yang masuk menjadi bagian Prolegnas DPR, Pemerintah maupun DPD memperhatikan kapasitas kelembagaan DPR dengan target Prolegnas yang akan dicapai, mengkaji secara mendalam kerangka konseptual, landasan filosofis, landasan yuridis maupun landasan sosiologis keberadaan RUU, dan komitmen politik secara kelembagaan baik Pemerintah, DPR maupun DPD dalam menyelesaikan Prolegnas.
\end{abstract}

Kata Kunci: peningkatan, prolegnas, integratif

\begin{abstract}
s
Low Prolegnas achievements both in terms of quantity and quality in the two periods of the National Legislation Program (Prolegnas): 2005-2009 and 2010-2014, is a crucial issue of law development that must be solved. The impact is not only the lack of achievement Prolegnas but the existence of the state of Indonesian law. This research identified two problems, first, what are the things that hinder the achievement of the Prolegnas target in the period 2005-2009 and the period 20102014? Second, how is the concept of improving the quality and quantity of Legislation in the future? This type of research is a normative juridical research. The study concluded that in order to improve the quality of Prolegnas then the Government and Regional Representatives Council (DPD) in the discussion of each bill by the House of Representatives (DPR), should pay attention to things, such as: the vertical harmonization of each Draft Bill's substance with the 1945 Constitution and the horizontal harmonization with legislation, the level of urgency and the compatibility of the laws' substance, and the legislative drafting capacity of legislatures. To improve the quantity of Prolegnas, in the drafting of each Draft Bill that is in the Prolegnas, the Government and the DPD should pay attention to things, such as: the institutional capacity of the $D P R$ with the Prolegnas target to be achieved, do an in depth conceptual framework studies, philosophical, juridical and sociological basis of the existence of the Draft Bill, and institutional political commitment of the Government, DPR and DPD in resolving Prolegnas.
\end{abstract}

Keywords: improving, national legislative program, integrative 


\section{A. Pendahuluan}

Program Legislasi Nasional (Prolegnas) sebagai instrumen pembentukan peraturan perundang-undangan nasional sering menjadi sorotan publik hampir setiap tahun karena dikaitkan dengan penilaian kinerja DPR dan Pemerintah sebagai lembaga yang diberi wewenang untuk membentuk undang-undang ${ }^{1}$. Sebagai lembaga legislasi, kinerja DPR dalam menghasilkan rancangan undang-undang (RUU) sering disoroti karena undang-undang yang dihasilkan tidak mencapai target yang ditetapkan baik target tahunan atau target lima tahunan. Buruknya kinerja DPR dalam menghasilkan undang-undang selalu dikaitkan dengan fasilitas dan gaji yang diperoleh Dewan Perwakilan Rakyat (DPR) yang begitu besar, tetapi tidak sebanding dengan prestasi kerja di bidang legislasi yang begitu minim².

Dua hal pokok yang menjadi sorotan publik adalah kuantitas dan kualitas undang-undang yang dihasilkan. Persoalan kuantitas fokus pada jumlah undang-undang yang dihasilkan tidak mencapai target yang ditetapkan dalam Prolegnas. Persoalan kualitas berkaitan dengan kualitas undang-undang yang rendah. Indikatornya adalah seringnya Mahkamah Konstitusi (MK) membatalkan undang-undang yang ditelah disahkan.

Persoalan Prolegnas diatasharus diselesaikan agar tidak berimbas pada keberadaan Indonesia sebagai negara hukum. Negara hukum yang menghendaki adanya legalitas pada semua kebijakan Pemerintah dalam menjalankan roda
Pemerintahan harus didasarkan pada undangundang akan terhambat karena undang-undang yang dibutuhkan tidak kunjung disahkan oleh DPR dan Pemerintah. Kehidupan kenegaraan yang sangat kompleks dipengaruhi globalisasi dan hukum internasional saat ini perlu mendapatkan regulasi hukum nasional untuk menjamin kehidupan ekonomi, bisnis, sosial, budaya dan politik berjalan dengan baik. Di samping itu, jika undang-undang yang dihasilkan cenderung bertentangan dengan UndangUndang Dasar Negara Republik Indonesia (UUD NRI 1945), maka berimbas pada terlanggarnya hak-hak warga negara dan terganggunya sistem hukum ${ }^{3}$.

Kondisi Prolegnas saat ini tidak boleh dibiarkan terus berlanjut karena berdampak pada tingkat kepercayaan masyarakat terhadap lembaga-lembaga negara khususnya DPR, Dewan Perwakilan Daerah (DPD) dan Pemerintah yang menyusun Prolegnas. Banyak pihak menganggap Prolegnas tidak lain adalah daftar kemauan DPR, tetapi tidak didukung oleh kemampuan untuk menyelesaikan pembahahasan sampai akhir masa sidang. Bahkan Prolegnas dianggap sebagai dokumen "macan kertas" yang hanya "gagah " di atas kertas, tetapi tidak mampu direalisasikan oleh lembaga yang menyusunnya sendiri (DPD, DPR dan Pemerintah). ${ }^{4}$

Oleh karena itu, perlu sebuah gagasan untuk mendesain peningkatan kualitas dan kuantitas Prolegnas yang dapat mewujudkan cita negara hukum yang tertuang dalam Konstitusi. 
Tulisan ini berusaha membangun konsep peningkatan kualitas dan kuantitas Prolegnas dalam mewujudkan cita negara hukum ${ }^{5}$. Untuk mendesain konsep tersebut, maka tulisan ini distrukturisasi dengan komponen pembahasan sebagai berikut: rasion'd etra Prolegnas, refleksi Prolegnas 2004-2009, Prolegnas 2010-2014, serta Prolegnas 2015-2019, pada bagian dari pembahasan akan dikonstruksi sebuah konsep pembahasan Prolegnas ke depan yang dapat menjamin kuantitas dan kualitas peraturan perundang-undangan.

Rendahnya capaian Prolegnas baik dari sisi kuantitas maupun kualitas pada dua periode Prolegnas (periode 2005-2009 dan periode 2010-2014) merupakan persoalan krusial pembangunan hukum yang harus dipecahkan. Dampaknya bukan saja minimnya capaian Prolegnas, tetapi pada eksistensi negara hukum Indonesia. Penelitian mengidentifikasi permasalahan dalam penelitian: Pertama, apakah hal-hal yang menghambat tercapainya target Prolegnas pada periode 2005-2009 dan periode 2010-2014? Kedua, bagaimanakah konsep peningkatan kualitas dan kuantitas Prolegnas pada masa yang akan datang?

\section{B. Metode Penelitian}

Jenis penelitian adalah penelitian yuridis normatif. Penelitian ini berusaha mendeskripsikan dan merefleksikan hambatan-hambatan capaian Prolegnaspada periode 2005-2009 dan periode 20102014 khususnya terkiat dengan kualitas dan kuantitas perundang-undangan dan berusaha menemukan konsep $^{6}$ kebijakan peningkatan kualitas dan kuantitas Prolegnas ke depan. Sejalan dengan jenis penelitian ini, maka pendekatan yang digunakan dalam penelitian ini adalah pendekatan peraturan perundangundangan dan pendekatan konseptual. Pendekatan peraturan perundang-undangan (statute approach) dilakukan dengan mengkaji berbagai peraturan perundang-undangan yang berkaitan dengan Prolegnas. Pendekatan konseptual dilakukan dengan mengkaji konsep kebijakan yang dapat mendukung peningkatan capaian Prolegnas. Data yang dibutuhkan dalam penelitian ini adalah bahan hukum primer, sekunder dan tersier. Bahan-bahan hukum tersebut diperoleh melalui studi kepustakaan (library research). Metode analisis yang digunakan untuk membedah masalah dalam penelitian dan menemukan konsep adalah dengan menggunakan analisis yuridis kualitatif. Pada analisis demikian bahan hukum tidak dianalisis dengan menggunakan rumus dan metode statistik yang menggunakan metode kuantitatif, tetapi menggunakan metode analisis hukum melalui pendekatan penafsiran hukum dan konstruksi hukum dengan cara berpikir deduktif?.

\section{Pembahasan}

\section{Rasion D' etre Prolegnas: Membangun Politik Hukum Sistimatis dan terencana dalam Bingkai Negara Hukum.}

Prolegnas merupakan instrumen perencanaan program pembentukan undang-undang yang disusun secara terencana, terpadu, dan

\footnotetext{
Moh.Mahfud MD, Permasalahan Aktual Koordinasi Prolegnas, Makalah disampaikan dalam lokakarya " 30 tahun Tahun Prolegnas, yang diadakan BPHN Kemenkumham RI, Hotel Sahid Jakarta, tanggal 19 s/d 21 oktober 2008, hlm. 2.

6 Sudikno Mertokusumo, Penemuan Hukum: Sebuah Pengantar (Jogjakarta: Liberty, 2003) hlm. 32.

7 Soetandyo Wignjosoebroto, Hukum: Konsep dan Metode, (Malang: Setara Press, 2013), hlm. 52.
} 
sistematis. Prolegnas dalam tataran operasional memuat daftar RUU yang disusun berdasarkan metode dan parameter tertentu serta dijiwai oleh visi dan misi pembangunan hukum nasional ${ }^{8}$.

Pada tataran filosofis, Prolegnas merupakan bagian pembangunan hukum yang bertujuan mewujudkan tujuan negara yang tertuang dalam konstitusi yaitu melindungi segenap rakyat dan bangsa, serta seluruh tumpah darah Indonesia, memajukan kesejahteraan umum, mencerdaskan kehidupan bangsa dan ikut melaksanakan ketertiban dunia yang berdasarkan kemerdekaan, perdamaian abadi, dan keadilan sosial melalui pembangunan hukum nasional.

Sebagai bagian dari pembangunan hukum nasional, Prolegnas dilakukan karena dua alasan, pertama, perubahan konstitusi yang mengukuhkan negara hukum sebagai pilar konstitusionalisme yang berimplikasi pada perubahan sistem ketatanegaraan. Kedua, perkembangan globalisasi yang dilegalkan melalui berbagai perjanjian internasional berimplikasi pada perubahan pola hubungan antara negara dengan maupun hubungan antara negara dan warga negara ${ }^{9}$.

Keberadan Prolegnas dalam pembangunan nasional dihadirkan untuk menata sistem hukum nasional secara menyeluruh dan terpadu, tidak dapat dilepaskan cita negara hukum (rechtstaat) yang tertuang dalam Pasal 1 ayat (3) UUD NRI Tahun 1945. Prinsip-prinsip negara hukum dimana menjadi instrumen tertinggi dalam penyelenggaraan kehidupan bernegara (supremasi hukum), persamaan kedudukan di hadapan hukum (equality before the law), serta menjadikan hukum sebagai landasan operasional dalam menjalankan sistem kehidupan bermasyarakat, berbangsa, dan bernegara ${ }^{10}$.

Dalam pembangunan nasional, supremasi hukum ditempatkan secara strategis sebagai landasan dan perekat bidang pembangunan lainnya serta kehidupan berbangsa dan bernegara dalam bingkai Negara Kesatuan Republik Indonesia melalui satu sistem hukum nasional. Untuk mewujudkan pembangunan hukum sebagai suatu sistem, maka Prolegnas dihajatkan juga untuk terealisasinya fungsifungsi hukum sebagai alat rekayasa sosial/ pembangunan (law as a tool of social engeneering), instrumen penyelesaian masalah (dispute resolution) dan instrumen pengatur perilaku masyarakat (social control). Supremasi hukum bermakna pula sebagai optimalisasi perannya dalam pembangunan, memberi jaminan bahwa agenda pembangunan nasional berjalan dengan cara yang teratur, dapat diramalkan akibat dari langkah-langkah yang diambil (predictability), yang didasarkan pada kepastian hukum (rechtszekerheid), kemanfaatan, dan keadilan (gerechtigheid). Pada fungsi yang lain pembangunan hukum yang dibentuk melalui Prolegnas diharapkan sebagai perekat kehidupan berbangsa dan bernegara ${ }^{11}$.

Pertimbangan pembentukan Prolegnas dapat kita lihat pada Prolegnas2005-2009 
yang akan ditampilkan di bawah. Pada bagian pendahuluan disebutkan bahwa urgensitas Prolegnas didasarkan pada kondisi objektif pelaksanaan program pembangunan nasiona hukum pada awal-awal reformasi (2000-2004) secara umum menggambarkan masih belum menunjukkan hasil pembangunan hukum yang sesuai dengan harapan dan rasa keadilan masyarakat, yaitu hukum yang sungguhsungguh memihak kepentingan rakyat, hukum yang tidak hanya melindungi kepentingan orang perseorangan dan kelompok/golongan tertentu, hukum yang tetap mengimplementasikan nilainilai hukum yang hidup di dalam masyarakat ${ }^{12}$.

Pertimbangan teoritis lahirnya Prolegnas mengikuti komponen sistem hukum yang dikemukakan Lawrence Friedman yaitu aspek substansi hukum, struktur hukum, dan budaya hukum. Komponen materi hukum masih ditemukan materi hukum yang saling tumpang tindih dan tidak konsisten, baik secara vertikal maupun horizontal, belum menunjukkan komitmen dan karakter yang responsif terhadap masalah perlindungan hak asasi manusia, masyarakat lemah dan marjinal, nilai keadilan jender, serta proses pembentukannya yang kurang aspiratif dan partisipatif ${ }^{13}$. Komponen aparatur hukum antara lain kurang memadainya integritas, moral dan profesionalisme aparat penegak hukum, serta belum terwujudnya lembaga hukum yang kuat dan terintegrasi ${ }^{14}$. Komponen budaya hukum yaitu masih rendahnya kepercayaan masyarakat terhadap hukum yang ditandai dengan terputusnya hubungan atau terjadi kesenjangan antara norma-norma hukum dan perilaku masyarakat ${ }^{15}$.

Ketiga problem pembangunan sistem hukum di atas disebabkan karena pembentukan peraturan perundang-undangan yang mengabaikan pentingnya kegiatan inventarisasi, sinkronisasi, harmonisasi seluruh peraturan perundang-undangan, serta kurang melakukan diseminasi peraturan perundangundangan untuk membuka akses dan meningkatkan partisipasi masyarakat dalam pembentukan undang-undang. Oleh karena itu, pembentukan undang-undang melalui Prolegnas menurut Ketua Baleg, 2009-2014, Ignatius Mulyono ${ }^{16}$, dihajatkan untuk dapat mewujudkan konsistensi undang-undang, serta meniadakan pertentangan antar undangundang (vertikal maupun horizontal) yang bermuara pada terciptanya hukum nasional yang adil, berdaya guna, dan demokratis. Selain itu dapat mempercepat proses penggantian materi hukum yang merupakan peninggalan masa kolonial yang sudah tidak sesuai dengan kebutuhan hukum masyarakat ${ }^{17}$.

Pada aspek yang lain Prolegnas merupakan instrumen perencanaan hukum yang

12 Moh.Mahfud M.D, Membangun Politik Hukum, Menegakkan Konstitusi (Jakarta: Pustaka LP3ES , 2006$)$ hlm.5.

13 Ni,matul Huda, Politik ketatanegaraan Indonesia: kajian terhadap dinamika perubahan UUD 1945, (Yogyakarta: FH UII, 2002,) hlm. 49.

14 Satya Arinanto,Politik Pembangunan Hukum Nasional dalam Era Pasca reformasi, Jurnal Konstitusi Volume 3 Nomor 3 September 2006, (2006), hlm. 79.

15 Jimly Asshiddiqie, Pengantar Ilmu Hukum Tata Negara, (Jakarta: Sekjen MK RI,2006) hlm. 34.

16 Igantius Mulyono, Kebijakan Penyusunan Prolegnas RUU Prioritas Tahun 2011, Makalah disampaikan dalam Rapat Pembahasan Tahunan Program Legislasi Nasional Tahun 2010, Badan pembinaan Hukum NasionalKementerian Hukum dan Hak Asasi Manusia, Bogor, 12 -14 Oktober 2010 hlm. 3.

17 Jimly Assidiqie, Perihal Undang-Undang, (Jakarta: Konstitusi Press, 2006), hlm. 50. 
menggambarkan sasaran politik hukum yang memuat daftar RUU yang dibentuk selaras dengan tujuan pembangunan hukum nasional ${ }^{18}$. Oleh karena itu, sasaran politik hukum nasional berkorelasi dengan Rencana Pembangunan Jangka Panjang Nasional (RPJPN) sebagai arah dan prioritas pembangunan secara menyeluruh yang dilakukan secara bertahap untuk mewujudkan masyarakat adil dan makmur sebagaimana diamanatkan oleh UUD NRI 1945. Prolegnas diperlukan sebagai potret politik undang-undang atau substansi politik hukum nasional untuk mencapai tujuan negara dalam kurun waktu tertentu, baik dalam membuat undang-undang baru maupun dalam mencabut atau mengganti undang-undang lama ${ }^{19}$.

\section{Refleksi Prolegnas 2005-2009 dan Prolegnas 2010-2014.}

Perencanaan pembentukan peraturan perundang-undangan melalui Prolegnas telah dilakukan pada tiga periode jabatan DPR terakhir (2004-200920 dan 2009-2014²). Pada dua masa jabatan itu pula kinerja DPR dalam capaian Prolegnas menjadi sorotan publik karena capaian lima tahunan (long list) maupun satu tahunan (short list) tidak tidak sesuai dengan target. Menurut penulis untuk memahami problematika yang mewarnai proses legislasi pada masing-masing periode jabatan legislatif tersebut penting untuk dikemukakan sebagai dasar untuk mengkonstruksi konsep peningkatan kualitas dan kuantitas Prolegnas.

\section{1) Prolegnas 2005-2009.}

Prolegnas 2005-2009 merupakan Prolegnas pertama yang disusun berdasarkan perintah Undang-Undang Nomor 10 Tahun 2004 tentang Pembentukan Peraturan Perundang-Undangan. Pada tahun 2005, DPR bersama Pemerintah telah menetapkan Prolegnas long list, 20052009 sebanyak 284 RUU.

Secara filosofikal, Prolegnas periode ini disusun berdasarkan pada isi pembangunan hukum nasional, yaitu " Terwujudnya negara hukum yang adil dan demokratis melalui pembangunan sistem hukum nasional dengan membentuk peraturan perundang-undangan yang aspiratif, berintikan keadilan dan kebenaran yang mengabdi kepada kepentingan rakyat dan bangsa di dalam bingkai Negara Kesatuan Republik Indonesia untuk melindungi segenap rakyat dan bangsa, serta tumpah darah Indonesia, memajukan kesejahteraan umum, mencerdaskan kehidupan bangsa dan ikut melaksanakan ketertiban dunia yang berdasarkan kemerdekaan, perdamaian abadi dan keadilan sosial berdasarkan Pancasila dan UUD NRI 1945".

Pada Prolegnas periode ini ditentukan arah kebijakan Prolegnas yang dimaksudkan untuk:

a) membentuk peraturan perundangundangan di bidang hukum, ekonomi, politik, agama, pendidikan, ilmu pengetahuan dan teknologi, sosial budaya, pembangunan daerah, sumber daya alam dan lingkungan hidup, pertahanan dan keamanan, sebagai pelaksanaan amanat UUD NRI 1945; 
b) mengganti peraturan perundang-undangan peninggalan kolonial dan menyempurnakan peraturan perundang-undangan yang ada yang sudah tidak sesuai lagi dengan perkembangan jaman;

c) mempercepat proses penyelesaian RUU yang sedang dalam proses pembahasan dan membentuk undang-undang yang diperintahkan oleh undang-undang;

d) membentuk peraturan perundangundangan yang baru untuk mempercepat reformasi, mendukung pemulihan ekonomi, perlindungan hak asasi manusia dan pemberantasan korupsi kolusi dan nepotisme dan kejahatan transnasional;

e) meratifikasi secara selektif konvensi internasional yang diperlukan untuk mendukung pembangunan ekonomi, demokrasi dan perlindungan hak asasi manusia serta pelestarian lingkungan hidup;

f) membentuk peraturan perundangundangan baru sesuai dengan tuntutan masyarakat dan kemajuan jaman;

g) memberikan landasan yuridis bagi penegakan hukum secara tegas profesional dan menjunjung tinggi hak asasi manusia dan prinsip-prinsip kesetaraan dan keadilan jender; dan

h) menjadikan hukum sebagai sarana pembaruan dan pembangunan di segala bidang yang mengabdi kepada kepentingan rakyat, bangsa dan negara guna mewujudkan prinsip keseimbangan antara ketertiban, legitimasi dan keadilan.
Dalam sebuah lokakarya yang diadakan di Bandung tahun 2009, yang kebetulan diikuti penulis, Ketua Badan Legislasi DPR periode 2004-2009, FX Soekarno menulis dalam makalahnya bahwa Prolegnas 2005-2009 telah menetapkan Prolegnas RUU Prioritas Tahun Anggaran (short list). Tahun 2005 ditetapkan sebanyak 55 RUU, tahun 2006 sebanyak 43 RUU, tahun 2007 sebanyak 32 RUU, tahun 2008 sebanyak 31 RUU dan tahun 2009 sebanyak 36 RUU. Dalam daftar Prolegnas Prioritas RUU terdapat daftar kumulatif terbuka, misalnya Pembentukan Daerah Otonom, Ratifikasi Perjanjian Internasional, Dampak Putusan MK dan Reformasi Agraria masing-masing dengan satu judul RUU 22 .

Namun pada akhir masa jabatan DPR 20042009, target legislasi sebanyak 284 RUU tidak tercapai. Menurut data yang disampaikan Baleg pada Juni 2009, target pembahasan RUU menjadi UU baru mencapai 160 undang-undang (56,33\%).

Menurut penelitian yang dilakukan Richo Wahyudi pada Fakultas Hukum Universitas Indonesia diperoleh data bahwa dari 284 RUU Prolegnas yang dapat disahkan menjadi undangundang sampai akhir masa jabatan DPR hanya 193 Undang-undang (71.7).

Selain persoalan kuantitas yang tidak sesuai dengan target, Prolegnas 2005-2009 menghadapi masalah kualitas undang-undang yang dihasilkan. Penelitian Richo Wahyudi kembali menjelaskan perincian undang-undang yang dihasilkan. Terdapat 58 RUU dengan kategori RUU tentang Pembentukan Daerah Otonom, 4 (empat) RUU tentang Pembentukan

22 FX. Soekarno, Arah Kebijakan Penyusunan Prolegnas 2010 - 2014, Makalah disampaiakan pada Lokakarya Prolegnas Tahun 2009, yang diselenggarakan oleh BPHN, Departemen Hukum dan HAM, tanggal 10 Juni 2009 , di Bandung, Jawa Barat, hlm. 
Pengadilan Tinggi Agama sebanyak 4 RUU, 9 RUU Kumulatif terbuka tentang pengesahan perjanjian internasional, 7 RUU Kumulatif terbuka akibat putusan MK sebanyak 7 RUU, RUU tentang APBN sebanyak 16 RUU, dan RUU tentang penetapan PERPU sebanyak 12 RUU. Semua kategori RUU tersebut secara substansi tidak membutuhkan pembahasan yang mendalam atau RUU copy paste saja, yang berbeda dengan kategori RUU Prolegnas yang pembahasannya perlu pendalaman yang serius.

Hasil penelitian PSHK tahun 2005-2009 menunjukkan rendahnya capaian target legislasi yang telah ditetapkan. Prolegnas periode pertama 2005-2009 menunjukkan tingkat capaian legislasi tahunan legislasi yang jauh dari harapan. Pada tahun 2005, target target legislasi 55 RUU, namun yang dapat disahkan hanya 14 undang-undang. Kondisi yang sama terjadi pada tahun 2006, dengan target legislasi sebanyak 76 RUU, namun yang disahkan menjadi undangundang hanya 39 undang-undang. Pada tahun
2007 RUU yang ditargetkan 78 RUU namun yang dapat disahkan adalah 40 Undang-undang. Pada tahun 2008 target legislasi sebanyak 81 namun yang dicapai sebesar 61 undangundang. Pada akhir masa jabatan tahun 2009 RUU yang ditargetkan sebanyak 76 RUU, namun yang disahkan hanya 39 Undang-undang.

Tidak tercapainya target legislasi 2005-2009 menurut ketua Badan Legislasi DPR RI tahun 2004-2009 disebabkan karena:

1) Penentuan jumlah RUU sebanyak 284 RUU pada tahun 2005 belum sepenuhnya menggunakan kriteria yang jelas dan tepat, dikaitkan dengan kebutuhan hukum yang ada. Penentuan judul yang masuk tidak disertai alasan mengenai urgensi RUU bahkan ada beberapa RUU yang memiliki kesamaan atau kedekatan substansi materi yang akan diatur.

2) Penentuan prioritas tahunan belum sepenuhnya memperhitungkan kapasitas dan ketersediaan waktu legislasi DPR. DPR

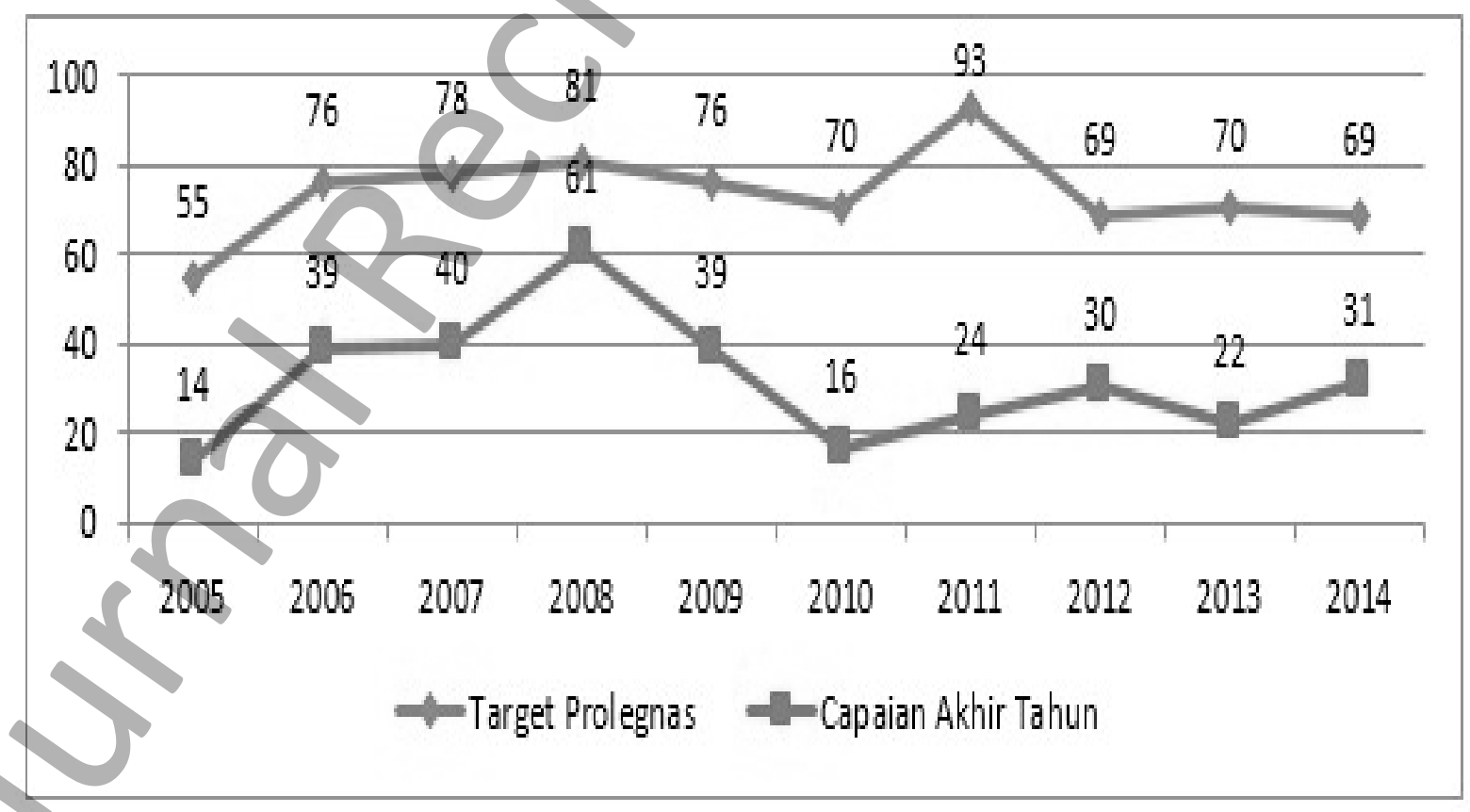

Sumber: PSHK, 2014. 
menjadwalkan hari legislasi 2 hari kerja dalam setiap minggu pada setiap Masa Persidangan.

3) Parameter yang digunakan untuk menentukan RUU yang akan dimasukan dalam Prolegnas sering kalah oleh kepentingan politik.

4) Komitmen terhadap Prolegnas sebagai satu-satunya instrumen perencanaan pembentukan undang-undang, belum sepenuhnya ditaati baik oleh Pemerintah maupun DPR, masih sering terjadi masuknya RUU yang sebelumnya tidak tercantum dalam daftar Prolegnas.

5) Mekanisme pembahasan RUU di lingkungan DPR membutuhkan waktu yang panjang, karena keharusan adanya DIM lebih dulu dan harus mendapatkan persetujuan semua fraksi dan Pemerintah.

\section{2) Prolegnas 2010-2014.}

Pada periode ke-2 Prolegnas (2010-2014), DPR dan Pemerintah telah menetapkan sebanyak 247 (dua ratus empat puluh tujuh) RUU dan 5 (lima) RUU Kumulatif Terbuka.

Penyusunan Prolegnas Tahun 2010-2014 didasarkan pada visi: mewujudkan negara hukum yang demokratis melalui pembangunan sistem hukum nasional dengan membentuk peraturan perundang-undangan yang aspiratif, berintikan keadilan dan kebenaran".Untuk menjalankan visi tersebut ditentukan misi Prolegnas sebagai berikut:

a) mewujudkan materi hukum yang sesuai dengan perkembangan dan kebutuhan hukum masyarakat;

b) mewujudkan partisipasi masyarakat dalam pembentukan peraturan perundangundangan; c) mewujudkan lembaga hukum yang mandiri, kredibel, adil, imparsial dan terintegrasi dalam satu sistem hukum; dan

d) mewujudkan aparatur hukum yang bersih, taat hukum, profesional, dan bertanggung jawab.

Prolegnas 2010-2014 disusun dengan maksud dan tujuan tertentu. Berdasarkan Keputusan Dewan Perwakilan Rakyat Republik Indonesia Nomor: 41 A/DPR RI/ I/2009-2010 Tentang Persetujuan Penetapan ProlegnasTahun 2010 - 2014 maksud Penyusunan Prolegnas Tahun 2010-2014 sebagai berikut:

a) Memberikan landasan perencanaan dan arahan yang sistematis dan berkelanjutan terhadap pembangunan jangka menengah yang berlandaskan kemampuan nasional dengan memanfaatkan kemajuan ilmu pengetahuan dan teknologi dalam mewujudkan masyarakat adil makmur.

b) Mengintegrasikan pembangunan nasional di bidang hukum yang secara spesifik diarahkan pada pembenahan dan penguatan sistem hukum nasional yang didasarkan pada UUD NRI 1945, tuntutan reformasi, serta kemajuan ilmu pengetahuan dan teknologi;

c) Meningkatkan sinergi antar lembaga yang berwenang membentuk undang-undang di tingkat pusat.

Adapun tujun yang hendak dicapai Prolegnas 2010 - 2014 adalah:

a) mewujudkan negara hukum yang demokratis melalui pembangunan sistem hukum nasional dengan membentuk undangundang yang menjamin kepastian hukum, kemanfaatan, keadilan, dan ketertiban;

b) mewujudkan supremasi hukum yang menjunjung tinggi rasa keadilan dan nilai- 
nilai hukum yang hidup dalam masyarakat; dan

c) menyempurnakan undang-undang agar sesuai dengan tuntutan dan kebutuhan masyarakat, serta berorientasi pada pengaturan perlindungan hak asasi manusia dengan memperhatikan prinsip-prinsip kesetaraan dan keadilan jender.

\section{3) Konsep Peningkatan Kualitas dan Kuantitas Prolegnas: Rekomendasi Konseptual dan Kebijakan Prolegnas 2015-2019.}

Uraian refleksi capaian Prolegnas di atas menunujukkan berbagai problematika yang menyelimuti Prolegnas yang harus ditemukan solusinya. Pada tulisan ini Penulis mengemukakan sebuah konsep peningkatan kualitas dan kuantitas Prolegnas. Konsep peningkatan kualitas maksudnya adalah bangunan konsep yang dikonstruksi dari berbagai elemen /postulat pendukung konsep. Begitu juga pada konsep peningkatan kuantitas dibangun dengan konstruksi berbagai elemen/ postulat pendukung konsep ${ }^{23}$.

Pada pembahasan dua aspek Prolegnas di atas, penulis membagi pembahasan dalam dua fokus pembahasan yaitu konsep peningkatan kualitas dan konsep peningkatan kuantitas. Walaupun terkesan terjadi dikotomi antara kedua konsep ini, tetapi tujuannya sama yaitu mewujudkan Prolegnas yang memiliki kualitas yang bagus, tetapi juga memiliki kuantitas sesuai dengan kebutuhan masyarakat. Pada akhirnya konsep yang ditawarkan pada tulisan ini adakah konsep Prolegnas integratif, yang mengintegrasikan aspek kualitas dan kuantitas produk legislasi ${ }^{24}$.

\section{a. Konsep Peningkatan Kualitas Prolegnas.}

Bangunan konsep peningkatan kualitas legislasi didasarkan pada kenyataan bahwa undang-undang sebagai produk legislasi selalu bermasalah pada tataran substansi. Indikatornya adalah undang-undang yang lahir sering menjadi objek judicial review di MK oleh warga negara, materi muatan yang tidak layak diatur dalam undang, materi muatan undangundang yang bertentangan satu sama lain (tidak harmonis dan tidak sinkron), dan minimnya kapasitas legislative drafting anggota DPR.

Elemen-elemen konsep yang dibangun dalam peningkatan kualitas Prolegnas, pertama, harmonisasi vertikal materi RUU dengan UUD NRI 1945. Hal ini penting dilakukan ketika proses pembahasan RUU pada pembicaraan tingkat I yang biasanya dilaksanakan oleh Panitia Khusus (Pansus) atau panitia kerja (Komisi) di DPR. Ketika pembahasan Pansus harus memastikan bahwa pasal-pasal dalam RUU berpotensi bertentangan dengan konstitusi. Penulis berpandangan pada tataran praktis Daftar Isian Masalah (DIM) yang disampaikan fraksi-fraksi di DPR harus fokus pada mengkaji setiap pasal dengan ketentuan konstitusi. Ketentuan RUU pasal harus disandingkan dengan pasal-pasal dalam konsistensi.

Kedua, pendalaman materi muatan yang menjadi lingkup pengaturan undang-undang. Selama ini seringkali terjadi materi muatan yang diatur dalam undang-undang sebenarnya materi muatan yang cukup diatur dalam 
peraturan Pemerintah atau undang-undang yang lahir telah didelegasikan melalui Peraturan Pemerintah. Oleh karena itu, untuk menghindari over regulation yang menimbulkan tumpang tindih pengaturan, maka ketika pengajuan RUU untuk dimasukkan dalam Prolegnas harus dikaji secara mendalam tingkat urgensitasnya dan tingkat koherensi dengan undang-undang yang lain. Jika memang beberapa materi muatan yang memiliki materi yang sama atau bersinggungan, maka cukup digabung dalam satu undang-undang saja. Begitu juga jika materi muatan yang diatur dalam Undangundang sebenarnya adalah materi muatan peraturan Pemerintah yang telah di delegasikan dalam undang-undang, maka tidak perlu diatur dengan undang-undang, tetapi cukup dengan peraturan Pemerintah saja ${ }^{25}$.

Ketiga, sinkronisasi materi muatan undangundang dengan undang-undang yang sederajat (sinkronisasi horizontal). Ini penting dilakukan untuk membangun kualitas undang-undang karena undang-undang yang tidak harmonis berdampak pada tumpang tindih kewenangan dalam Pemerintahan. Oleh karena itu, ketika pembahasan RUU pada tingkat pertama sinkronisasi horizontal menjadi penting dilakukan untuk menjamin bahwa undangundang yang lahir kemudian tidak bertentangan dengan sistem yang telah dibentuk yang tentu akan menyulitkn jalannya Pemerintahan.

Keempat, peningkatan kapasitas legislative drafting anggota DPR. Pemikiran ini didasarkan pada pertimbangan bahwa tidak semua anggota DPR memiliki latar belakang pendidikan hukum atau memahami teknik dan teori penyusunan peraturan perundang-undangan yang mumpuni. Oleh karena itu, menurut penulis penting bagi lembaga DPR untuk melakukan peningkatan kapasitas bagi anggota DPR di bidang legis/ative drafting.

\section{b. Konsep Peningkatan Kuantitas Prolegnas}

Untuk membangun konsep peningkatan kuantitas output Prolegnas, maka dimulai dari elemen-elemen pendukung konsep tersebut. Bangunan konsep itu berangkat dari kondisikondisi yang menghambat tercapainya targettarget legislasi yang telah ditetapkan dalam Prolegnas.

Menurut penulis, kondisi-kondisi yang menghambat tercapainya Prolegnas berangkat dari beberapa penyebab, yaitu: pertama, RUU yang diajukan pengusul tidak disertai dengan kajian mendalam mengenai landasan konseptual, landasan filosofis, sosiologis, atau yuridis. Seringkali RUU yang diajukan hanya judul RUU saja tanpa disertai alasan konseptual yang menjadi landasan berpikir dan pijakan ${ }^{26}$.

Kedua, mekanisme kerja pembahasan RUU di DPR yang tidak sistimatis. Penyediaan hari kerja untuk legislasi di DPR tidak proporsional dibandingkan dengan beban kerja legislasi. Penyediaan 2 (dua) hari kerja setiap minggu untuk legislasi belum proporsional dibandingkan dengan hari pengawasan, hari anggaran dan hari fraksi (jum'at). Belum lagi dengan banyaknya waktu reses dan jadwal kunjungan kerja DPR baik di dalam maupun luar negeri menjadikan energi DPR untuk legislasi menjadi berkurang.

Ketiga, komitmen politik yang minim. Seringkali terjadi terhambatnya capaian

25 Sunaryati Hartono, Program Legislasi Nasional Antara Kenyataan Dan Harapan, dalam Ibid, hlm. 266.

26 Sri Soemantri, Penyusunan Naskah Akademik Pengharmonisan Draf Ruu Dalam Mengantisipasi Potensi Judicial Review Oleh Mahkamah Konstitusi, dalam Ibid, hlm. 266. 
Prolegnas karena kurangnya kemauan politik dari anggota DPR, fraksi, alat kelengkapan DPR maupun Pemerintah untuk menyelesaikan tugas-tugas legislasi. Seringkali terjadi anggota DPR atau Pemerintah malas untuk menghadiri rapat pembahasan karena kesibukan tugas masing-masing atau sengaja tidak mau menghadiri rapat.

Oleh karena itu penulis berpendapat untuk meningkatkan kuantitas legislasi, maka perlu dibangun elemen-elemen konseptual untuk memperbaiki kondisi yang ada.

Pertama, RUU yang diajukan pengusul harus disertai kajian konseptual yang mendalam ketika sebuah RUU diusulkan untuk masuk dalam Prolegnas. Keberadaan kajian konseptual awal menghilangkan kesan bahwa masuknya RUU dalam Prolegnas bukan karena titipan institusi tertentu, tetapi menjadi landasan bagi DPR dan Pemerintah dalam mendesaian Naskah Akademik dan RUU.

Kedua, membangun mekanisme kerja legislasi yang efisien dan sistimatis. Mekanisme kerja yang efektif dan efisien dilakukan dengan menyediakan perhatian kelembagaan Pemerintah dan DPR untuk memberikan porsi waktu yang lebih banyak pada hari legislasi dari hari-hari kerja yang lain di DPR.

Ketiga, komitmen politikinstitusi dan anggota DPR yang maksimal. Tingginya komitmen politik institusional baik Pemerintah maupun DPR untuk menyelesaikan tugas-tugas konstitusional merupakan modal penting dalam mendukung tercapainya Prolegnas. Komitmen politik tersebut lahir dari komitmen individual anggota DPR, fraksi-fraksi di DPR, alat kelengkapan maupun Pemerintah dalam memaksimalkan capaian target legislasi.

\section{Penutup}

Faktor yang menghambat tercapainya target Prolegnas baik dari sisi kualitas maupun kuantitas pada periode 2005-2009 dan periode 2010-2014 adalah: pada sisi kualitas, terjadi kondisi disharmonis antara materi muatan undang-undang dengan UUD NRI 1945, materi muatan undang-undang yang tidak layak diatur dalam undang-undang, materi muatan undangundang yang bertentangan satu sama lain (tidak harmonis dan tidak sinkron), dan minimnya kapasitas legislative drafting anggota DPR. Pada sisi kuantitas. Faktor yang menghambat tercapainya target legislasi nasional adalah: RUU yang diajukan pengusul tidak disertai dengan kajian mendalam mengenai landasan konsepsional, landasan filosofis, sosiologis maupun yuridis, mekanisme kerja pembahasan RUU di DPR yang tidak sistimatis dan komitmen politik yang minim untuk menyelesaikan Prolegnas.

Konsep yang ditawarkan dalam peningkatan Prolegnas adalah konsep penyusunan Prolegnas integratif, yang menggabungkan aspek kualitas dan kuantitas produk legislasi. Pada konsep demikian hambatan-hambatan yang terdapat dalam Prolegnas baik dari sisi kualitas maupun kuantitas diharapkan dapat diatasi.

Guna meningkatkan kualitas Prolegnas, maka ketika pembahasan RUU oleh DPR, Pemerintah dan DPD hendaknya memperhatikan hal-hal: harmonisasi vertikal materi RUU dengan UUD NRI 1945 dan harmonisasi horizontal RUU dengan peraturan perundang-undngan, tingkat urgensitas dan kompatibilitas materi muatan undang-undang, dan peningkatan kapasitas legislative drafting anggota legislatif. Dan untuk menjamin peningkatan kuantitas Prolegnas, maka hendaknya ketika penyusunan RUU yang masuk menjadi bagian Prolegnas DPR, 
Pemerintah maupun DPD memperhatikan: kapasitas kelembagaan DPR dengan target Prolegnas yang akan dicapai, mengkaji secara mendalam kerangka konsepsional, landasan filosofis, landasan yuridis maupun landasan sosiologis keberadaan RUU, dan komitmen politik secara kelembagaan baik Pemerintah, DPR maupun DPD dalam menyelesaikan Prolegnas.

\section{DAFTAR PUSTAKA}

\section{Buku}

Asshiddiqie, Jimly, Perihal Undang-Undang (Jakarta: Konstitusi Press, 2006)

Asshiddiqie, Jimly, Pengantar Ilmu Hukum Tata Negara (Jakarta: Sekjen MK RI,2006)

Badan Pembangunan Hukum Nasional, Tiga Dekade Prolegnasdan BPHN (Jakarta, BPHN: 2004 )

Farida S, Maria, Ilmu Perundang-undangan: Jenis, Fungsi dan Materi Muatan (Yogyakarta: Kanisius, 2007)

Firmansyah, Rachmad Maulana, et, al, Catatan Kinerja DPR 2012: Fondasi Tahun Politik (Jakarta: PSHK, 2013)

Huda, Ni'matul, Politik ketatanegaraan Indonesia: kajian terhadap dinamika perubahan UUD 1945 (Yogyakarta: FH UII, 2002)

Isra, Saldi, Kekuasaan dan Perilaku Korupsi: catatan Hukum (Jakarta: Kompas Media Nusantara, 2009)

Kusumaatmadja, Mochtar, Konsep-Konsep Hukum dalam Pembangunan: Kumpulan Karya Tulis Prof.Dr. Mochtar Kusumaatmadja, SH.,LL.M (Bandung: Alumni, 2002)
Mahfud M.D, Moh., Membangun Politik Hukum, Menegakkan Konstitusi (Jakarta: Pustaka LP3ES, 2006)

Mertokusumo, Sudikno, Penemuan Hukum: Sebuah Pengantar (Jogjakarta: Liberty, 2003)

Pusat Studi Hukum dan Kebijakan, Legislasi: Aspirasi atau Transaksi: Catatan Kinerja DPR 2011 (Jakarta: PSHK, 2012)

Rahardjo, Satjipto, IImu Hukum (Bandung: Citra Aditya, 2000)

Rasjidi, Lili, dan I.B.Wyasa Putra, Hukum Sebagai Suatu Sistem (Bandung, Mandar Maju: 2003).

Wignjosoebroto, Soetandyo, Hukum: Konsep dan Metode (Malang: Setara Press, 2013)

\section{Makalah/Artikel/Prosiding/Hasil Penelitian}

Soekarno, FX., Arah Kebijakan Penyusunan Prolegnas 2010 - 2014, Makalah disampaiakan pada Lokakarya Prolegnas Tahun 2009, yang diselenggarakan oleh BPHN, Departemen Hukum dan HAM, tanggal 10 Juni 2009, di Bandung, Jawa Barat

Mulyono, Ignatius, Kebijakan Penyusunan Prolegnas RUU Prioritas Tahun 2011, Makalah disampaikan dalam Rapat Pembahasan Tahunan ProlegnasTahun 2010, Badan pembinaan Hukum Nasional-Kementerian Hukum dan Hak Asasi Manusia, Bogor, 12 -14 Oktober 2010

Mahfud MD, Moh., Permasalahan Aktual Koordinasi Prolegnas, Makalah disampaikan dalam lokakarya " 30 tahun Tahun Prolegnas, yang diadakan BPHN Kemenkumham RI, Hotel Sahid Jakarta, tanggal 19 s/d 21 oktober 2008

Arinanto, Satya, Politik Pembangunan Hukum Nasional dalam Era Pasca reformasi, Jurnal Konstitusi Volume 3 Nomor 3 September 2006, (2006) 